\author{
ІНКЛЮЗИВНІ ІГРИ ЯК ФОРМА ВДОСКОНАЛЕННЯ ПРОФЕСІЙНОЇ \\ КОМПЕТЕНТНОСТІ ПЕДАГОГІВ \\ INCLUSIVE GAMES AS A FORM OF PROFESSIONAL IMPROVEMENT
OF TEACHERS' COMPETENCIES
}

УДК 37.042-056.2/.3:796(045)

DOI https://doi.org/10.32843/2663-

$6085 / 2021 / 39.20$

\section{Аксьонова О.П.,}

канд. пед. наук, доцент,

завідувачка кафедри реабілітаційної педагогіки та здорового способу життя КЗ «Запорізький обласний інститут післядипломної педагогічної освіти» Запорізької обласної ради

\section{Півненко Ю.В.,}

канд. пед. наук, доцент,

доцент кафедри реабілітаційної педагогіки та здорового способу життя КЗ «Запорізький обласний інститут післядипломної педагогічної освіти» Запорізької обласної ради
Інклюзивна освіта $\epsilon$ одним із потужних напрямів реформування України як сучасної країни світового рівня. Однак, оскільки механізм інклюзивних спортивних змагань ще не відпрацьований, існує певний методичний вакуум у контексті такої сфрери інклюзивної oсвimu.

Порівняння цілей і завдань адаптивної фрізичної культури зі стратегіями вчителя щодо інклюзивного фрізичного виховання дозволило авторам виявити певні протиріччя між традиційними підходами до організації позашкільних форм фрізичного виховання та принципами інклюзивної освіти, а також виділити позиції розробки методів визначення освітнього есректу проєкту «Перші інклюзивні ігри».

Метою статті є обгрунтування методу визначення освітнього есректу проєкту «Перші інклюзивні ігри». Проєкт унікальний за своїм змістом і форммтом реалізації в освітньому просторі України й за кордоном. Його складовими частинами є: підготовка вчителів у фоормі семінарів; консультації з керівниками команд-учасниць (онлайн); підготовка команд-учасниць до участі в Іграх; участь у самих Іарах.

Методи визначення освітнього есректу проєкту «Перші інклюзивні ігри» містять п'ять розділів: компетентнісна освіта; життєво важлива освіта; персональна освіта; кооперативна освіта; освіта, орієнтована на здоров'я. Коженіз розділів містить трипоказники. Зміст схеми, яка визначила освітній есрект проєкту, відбиває сучасний погляд на інклюзивну освіту загалом, а також на місію вчителів в інклюзії. Емпіричне дослідження дозволило встановити позитивну динаміку в самооцінці учасників семінару, в оцінках керівника семінару до початку тренінгу, після його завершення та підбивання підсумків Перших інклюзивних ігор «Ми разом». у перспективі автори планують відпрацювати методику визначення освітнього ефректу інших фрорм підвищення кваліфрікації педагогічних працівників; скорегувати (модернізувати) навчальні завдання для педагогів щодо складових частин схеми визначення освітнього ефректу.

Ключові слова: освіта, методика навчання, інклюзія, підвищення квалісрікації, педагог, семінар, проєкт, фрізичне виховання.
Inclusive education is one of the powerful directions of the reform of Ukraine as a modern world-class country. However, as the mechanism for inclusive sports competitions has not been worked out yet, there is some methodological vacuum in the context of this area of inclusive education.

Comparison of goals and objectives of adaptive physical culture with a teacher's strategies for inclusive physical education allowed the authors to identify some contradictions between traditional approaches to the organization of extracurricular forms of physical education and the principles of inclusive education as well as to highlight the positions for the development of methods for determining the educational effect of the project "The First Inclusive Games".

The purpose of the article is to substantiate the method of determining the educational effect of the project "The First Inclusive Games". This project is unique in its content and the format of realization in the educational space of Ukraine and abroad. Its components are: training of teachers in the form of seminars; consulting the leaders of participating teams (online); preparation of participating teams for participation in the Games; participation in the Games itself. Methods for determining the educational effect of the project "The First Inclusive Games" contains five sections: competency-based education; vital education; personalized education; cooperative education; health-centered education. Each of the sections includes three indicators. The content of the scheme, which determined the educational effect of the project, reflects the modern view of inclusive education in general as well as the mission of teachers in inclusion. An empirical study allowed establishing positive dynamics in the self-assessment of the participants of the seminar, in the assessments of the seminar leader before the start of the training, upon its completion and after summing up the results of the First Inclusive Games "We Are Together". We also plan to work out the method of determining the educational effect of other forms of professional development for teachers; adjustment (modernization) of educational tasks for teachers in relation to the components of the scheme for determining the educational effect. Key words: education, teaching methods, inclusion, improvement of the qualifications, teacher, seminar, project, physical education.
Постановка проблеми в загальному вигляді. Інклюзивна освіта - один із потужних напрямів ресорми України як сучасної держави світового рівня. Найбільш значущий ефект інклюзії - соціалізація людей з особливими освітніми потребами, рівний доступ до освіти.
На сьогодні унормоване додаткове кадрове забезпечення освітнього процесу (введені посади асистента вихователя / учителя групи / класу 3 інклюзивним навчанням); проведення корекційно-розвиткової роботи в закладах освіти 3 інклюзивним навчанням. У структурі корекційно- 
розвиткової роботи передбачено проведення занять 3 лікувальної фрізичної культури 3 дітьми та підлітками, які мають особливі освітні потреби. На жаль, більшість фрахівців проводять заняття 3 лікувальної фрізичної культури за старою методикою, яка побудована на принципах обмежень та відновлення. Ефект таких занять тимчасовий. Досвід інклюзивної освіти зарубіжжя свідчить про перспективність проведення занять адаптивною фрізичною культурою із залученням учасників різних типологічних груп. Соціалізація людини засобами адаптивної фрізичної культури передбачає не лише тренування, а й публічну демонстрацію своїх досягнень. Йдеться про участь у турнірах, змаганнях спортивного характеру. Однак сьогодні не відпрацьований механізм проведення інклюзивних спортивних змагань. У світі продовжує панувати спеціальна олімпіада, паралімпійські ігри, особливістю яких $€$ змагання між учасниками, які мають конкретні нозології, і відповідне до нозологічних ознак учасників суддівство.

Саме методичний вакуум у контексті зазначеного напряму інклюзивної освіти зумовлює актуальність проблеми.

Аналіз останніх досліджень і публікацій. У Національній стратегії розвитку освіти в Україні наголошено на зосередженні «зусиль, ресурсів на розв'язанні найбільш гострих проблем, які стримують розвиток, не дають можливості забезпечити нову якість освіти, адекватну нинішній історичній епосі». Серед гострих проблем виокремлено зокрема «відсутність цілісної системи виховання, фрізичного, морального та духовного розвитку і соціалізації дітей та молоді» [5]. Адаптивна фрізична культура в Україні - відносно молода дисципліна. Однак вищі навчальні заклади вже готують фрахівців цієї освітньої галузі. Адаптивна фрізична культура визначається як «соціальний феномен, головною метою якого $€$ соціалізація людей з обмеженими фрізичними можливостями, а не тільки їх лікування за допомогою фрізичних вправ і фрізіотерапевтичних процедур» [3, с. 4]. М. Трояновська метою занять адаптивною фрізичною культурою вбачає «окультурення» тіла людини, її оздоровлення, емоційно-ціннісне фрормування особистості, самореалізацію людини [7, с. 4-5]. За словами автора, адаптивна фрізична культура для тих, хто нею займається, «є єдиним способом «розірвати» замкнутий простір, увійти в соціум, знайти нових друзів, отримати можливість для спілкування, повноцінних емоцій, пізнання світу тощо. Саме тут, найчастіше вперше у своєму житті, вони пізнають радість руху, вчаться перемагати і гідно переносити поразки, усвідомлюють щастя подолання себе» [7, с. 6].

Концепцією розвитку інклюзивної освіти зазначені такі принципи: забезпечення рівного доступу до освіти; розвиток природних здібностей людини; особистісно-орієнтований підхід до кожного учасника освітнього процесу; освітня інтеграція; задоволення базових потреб особистості; системність педагогічних дій та ін. [6].

Авторами DINIZ, Rakel Pereira; VIANA, Fabiana Cury зазначені стратегії вчителя 3 інклюзивного фрізичного виховання. Зокрема, фрокусування на вміннях дитини, а не на ії̈ невміннях; стимулювання соціальної інтеграції; стимулювання як групових, так і одноосібних рухових дій; поєднання різних видів функцій під час здійснення певного рухового завдання; використання власного тіла для спілкування та самовираження; стимулювання креативності учнів та розвиток мови тіла; орієнтація на вікові особливості учасників, щоб психомоторні та соціальні ситуації були пов'язані з реальністю; моделювання життєздатних та безпечних ситуацій; керування діяльністю учасників так, щоб за такої умови було комфортно усім без винятку; пропонування рухових завдань, які сприяють появі впевненості в собі, підвищенню індивідуального потенціалу; перш ніж пропонувати допомогу, запитати про її необхідність в учня; завжди ставитися ввічливо, терпляче, відверто; розвивати звички, які стимулюють збільшення кількості та покращення якості здоров'я [1]

Виділення не вирішених раніше частин загальної проблеми. Зіставлення мети та завдань адаптивної фрізичної культури [3; 7] із зазначеними вище стратегіями вчителя інклюзивного фрізичного виховання дозволило виявити суперечності між традиційними підходами до організації позаурочних форм фрізичного виховання та принципами інклюзивної освіти; виокремити позиції для розробки методики визначення освітнього ефректу проєкту «Перші інклюзивні ігри».

Мета статті - обґрунтування методики визначення освітнього ефректу проєкту «Перші інклюзивні ігри» в межах удосконалення профресійної компетентності педагогів.

Виклад основного матеріалу. Перші інклюзивні ігри «Ми разом» (далі - Ігри) проведені 01-09 квітня 2021 року в Запорізькій області. Цей захід частина навчально-методичного проєкту, складовими частинами якого стали: навчання педагогів у формі семінарських занять; консультація керівників команд учасників (онлайн); підготовка команд учасників до участі в Іграх; безпосередньо участь в Іграх. Проєкт - унікальний за змістом і форматом проведення в освітньому просторі України та зарубіжжя, розроблений згідно 3 Національною стратегією розбудови безпечного і здорового освітнього середовища у новій українській школі на 2020-2024 роки, за напрямом «Створення сучасного, розвивального, безпечного, комфортного та інклюзивного освітнього середовища, яке сприяє збереженню та зміцненню здоров'я, захисту від небезпек, підвищенню рухової активності дітей» та 
на виконання Програми розвитку освіти Запорізької області на 2018-2022 роки, затвердженої рішенням Запорізької обласної ради від 30 листопада 2017 року № 54. Тривалість проєкту - два роки.

3 метою підвищення рівня профресійної компетентності педагогічних працівників щодо організації та проведення інклюзивних ігор серед дітей і підлітків була розроблена освітня програма семінару «Особливості підготовки до перших інклюзивних ігор «Ми разом». Навчання за програмою семінару як однією із фрорм підвищення кваліфрікації педагогічних працівників передбачало комплексне поєднання таких напрямів підготовки: розвиток професійних компетентностей (знання навчального предмета, фрахових методик, технологій); фрормування у здобувачів освіти спільних для ключових компетентностей вмінь; створення безпечного та інклюзивного освітнього середовища, особливості (специфіка) інклюзивного навчання, забезпечення додаткової підтримки в освітньому процесі дітей з особливими освітніми потребами; розвиток мовленнєвої, цифррової, комунікаційної, інклюзивної, емоційно-етичної компетентностей $[4 ; 6]$.
Основні завдання семінару: формувати компетентності педагогічних працівників щодо розробки та впровадження в урочну та позаурочну форму роботи з фрізичного виховання різних форм активності, участь в яких можуть безбар'єрно брати діти й підлітки різних типологічних груп; удосконалити раніше набуті й / або набуття нових компетентностей у межах професійної діяльності з урахуванням принципів інклюзивної освіти; розробити Положення про перші інклюзивні ігри «Ми разом».

Категорія слухачів: вчителі-реабілітологи інклюзивно-ресурсних центрів; фрахівці з освітніх осередків, які відповідають за проєкт.

Профресійні компетентності, які розвиваються на семінарі - фрахові (предметні) компетентності (далі - ФК):

- ФК-1. Глибокі знання та розуміння. Здатність аналізувати систему фрізичного виховання в контексті принципів інклюзивної освіти.

- ФК-2. Навички планування. Здатність розуміти та уміло використовувати прийоми моделювання, логічного поєднання дидактичних одиниць до єдиної гнучкої системи.

Таблиця 1

Навчально-тематичний план семінару «Особливості підготовки до перших інклюзивних ігор «Ми разом»

\begin{tabular}{|c|c|c|c|}
\hline Зміст навчального модуля & $\begin{array}{c}\text { Аудиторна форма } \\
\text { навчання }\end{array}$ & $\begin{array}{l}\text { Онлайн- } \\
\text { навчання }\end{array}$ & Разом \\
\hline Сесія 1. Актуальність та універсальність проєкту (30.01.2020) & 4 & & 4 \\
\hline $\begin{array}{l}\text { Тема 1.1. Державні вимоги до інклюзивної освіти як індикатор онов- } \\
\text { лення методики адаптивної фрізичної культури }\end{array}$ & 2 & & 2 \\
\hline $\begin{array}{l}\text { Тема 1.2. Методика підготовки учнів до виконання ігрового виду } \\
\text { «Паперові крила» }\end{array}$ & 1 & & 1 \\
\hline $\begin{array}{l}\text { Тема 1.3. Методика підготовки учнів до виконання ігрового } \\
\text { завдання «Шаро-моче-BALL» }\end{array}$ & 1 & & 1 \\
\hline $\begin{array}{l}\text { Сесія 2. Креативні тілесно-орієнтовані та екстремальні прак- } \\
\text { тики учнів, які мають особливі освітні потреби (11.03.2020) }\end{array}$ & 2 & 2 & 4 \\
\hline $\begin{array}{l}\text { Тема 2.1. Методика організації креативної рухової активності учнів, } \\
\text { які мають особливі освітні потреби }\end{array}$ & 1 & 1 & 2 \\
\hline $\begin{array}{l}\text { Тема 2.2. Методика організації екстремальної практики учнів, які } \\
\text { мають особливі освітні потреби }\end{array}$ & 1 & 1 & 2 \\
\hline $\begin{array}{l}\text { Сесія 3. Методичні рекомендації про Перші інклюзивні ігри } \\
\text { (04 лютого } 2021 \text { року) }\end{array}$ & & 4 & 4 \\
\hline $\begin{array}{l}\text { Тема 3.1. Термін проведення, вимоги до учасників, визначення } \\
\text { переможців }\end{array}$ & & 1 & 1 \\
\hline Тема 3.2. Специфріка суддівства ігрових завдань & & 3 & 3 \\
\hline PA30M: & 6 & 6 & 12 \\
\hline Кредит & \multicolumn{3}{|c|}{0,4} \\
\hline
\end{tabular}

Таблиця 2

Перелік номінацій, склад команд учасників і назв завдань Перших інклюзивних ігор «Ми разом»

\begin{tabular}{|l|l|l|}
\hline \multicolumn{1}{|c|}{ Назва номінацій } & \multicolumn{1}{|c|}{ Учасники } & \multicolumn{1}{|c|}{ Завдання } \\
\hline «Віртуоз» & $\begin{array}{l}\text { Один учасник: дитина з особливими освітніми потре- } \\
\text { бами одноосібно }\end{array}$ & $\begin{array}{l}\text { Ігрове завдання «Паперові крила. } \\
\text { Тривалість» }\end{array}$ \\
\hline «Потужний дует» & $\begin{array}{l}\text { Два учасника: дитина з особливими освітніми потре- } \\
\text { бами + дитина, яка має нормотиповий розвиток }\end{array}$ & Ігрове завдання «Парний кроссріт» \\
\hline «Витривала команда» & $\begin{array}{l}\text { Три учасника: дитина з особливими освітніми потре- } \\
\text { бами + дитина, яка має нормотиповий розвиток + } \\
\text { представник педагогічної спільноти }\end{array}$ & $\begin{array}{l}\text { Iгрове завдання «Шаро-моче- } \\
\text { ВALL» }\end{array}$ \\
\hline
\end{tabular}


- ФК-3. Експериментальні навички. Здатність описувати, аналізувати та критично оцінювати нововведення у освітній процес 3 інклюзивного фрізичного виховання.

Результати успішного опанування програми: впровадження в освітній процес перспективних оздоровчих практик і фрітнес-методики; відпрацювання на практиці завдань 3 дітьми та підлітками, які мають особливі освітні потреби; участь в розробці Положення про перші інклюзивні ігри «Ми разом».

Розпочинали навчання на семінарі 30 учасників. Завершили програму семінару 17 учасників.

Навчально-тематичний план семінару був розрахований на три сесії. Загальне навчальне навантаження становило 12 годин (0,4 кредиту) (табл. 1).

Ситуація, пов'язана з пандемією Covid-19, змінили фрормат проведення Ігор. Керівникам команд було запропоновано зняти відео виконання учасниками завдань згідно з методичними рекомендаціями; надіслати відео оргкомітету разом зі сканкопією заявки на участь. Відео розміщувалося на канал YouTube. Учасники суддівської бригади визначали результати виконання завдань, заповнювали відповідні протоколи. Відео та протоколи - в загальному доступі для перегляду в Інтернет-мережі. Учасники змагалися в трьох вікових категоріях: вихованці закладів дошкільної освіти; учні 1-4 класів; учні 5-11 класів. Завдання, які

Таблиця 3

Результати визначення освітнього ефекту проєкту «Перші інклюзивні ігри»

\begin{tabular}{|c|c|c|c|c|}
\hline Показники & $\begin{array}{c}\text { До навчання } \\
(30.01 .2020)\end{array}$ & $\begin{array}{l}\text { По завершенні } \\
\text { навчання } \\
\text { (04.02.2021) }\end{array}$ & $\begin{array}{c}\text { Після } \\
\text { підсумків ігор } \\
\text { (15.04.2021) }\end{array}$ & $\begin{array}{l}\text { Динаміка } \\
\text { «до і після» }\end{array}$ \\
\hline КОМПЕТЕНТНІСНО ОРІЄНТОВАНА ОСВІТА & 2,1675 & 4,1135 & 5,139 & 2,9715 \\
\hline $\begin{array}{l}\text { Уміння висловлювати власну думку усно і } \\
\text { письмово. Критичне та системне мислення, } \\
\text { здатність логічно обґрунтовувати позицію }\end{array}$ & 0,5555 & 1,1175 & 1,702 & 1,1465 \\
\hline Творчість, ініціативність & 1,201 & 1,761 & 1,882 & 0,681 \\
\hline $\begin{array}{l}\text { Вміння конструктивно керувати емоці- } \\
\text { ями, оцінювати ризики, приймати рішення, } \\
\text { розв'язувати проблеми. Здатність співпрацю- } \\
\text { вати з іншими людьми }\end{array}$ & 0,411 & 1,235 & 1,555 & 1,144 \\
\hline ЖИТТЄЗНАЧУЩА ОСВІТА & 2,261 & 4,4615 & 5,1395 & 2,8785 \\
\hline $\begin{array}{l}\text { Практика залучення учнів з особливими } \\
\text { потребами до освітнього процесу й життя } \\
\text { звичайного дитячого колективу }\end{array}$ & 1 & 1,4375 & 1,4375 & 0,4375 \\
\hline $\begin{array}{l}\text { Прийоми побудови наскрізного освітнього } \\
\text { процесу, який фрормує цінності }\end{array}$ & 0,7055 & 1,586 & 1,761 & 1,0555 \\
\hline $\begin{array}{l}\text { Інклюзивні практики, які допомагають краще } \\
\text { підготувати до реального життя усіх учнів }\end{array}$ & 0,5555 & 1,438 & 1,941 & 1,3855 \\
\hline ПЕРСОНАЛІЗОВАНА ОСВІТА & 1,522 & 3,821 & 4,937 & 3,415 \\
\hline $\begin{array}{l}\text { Інклюзивна практика фрормування } \\
\text { позитивного образу власного «Я» } \\
\text { учасників освітнього процесу }\end{array}$ & 0,5555 & 1,586 & 1,761 & 1,2055 \\
\hline $\begin{array}{l}\text { Прийоми заохочення, стимулювання } \\
\text { кожного учня }\end{array}$ & 0,5555 & 1 & 1,941 & 1,3855 \\
\hline $\begin{array}{l}\text { Методика адаптації навчальних програм, } \\
\text { дифреренціації навчальних завдань за умов } \\
\text { створення зони найближчого розвитку учнів } \\
\text { різних типологічних груп }\end{array}$ & 0,411 & 1,235 & 1,235 & 0,824 \\
\hline КООПЕРАТИВНА ОСВІТА & 2,312 & 3,877 & 4,5495 & 2,2375 \\
\hline $\begin{array}{l}\text { Технології побудови / моделювання освітнього } \\
\text { процесу на принципах педагогіки партнерства }\end{array}$ & 0,7 & 1,586 & 1,671 & 0,971 \\
\hline Досвід підтримки різноманітності & 1,201 & 1,441 & 1,761 & 0,56 \\
\hline $\begin{array}{l}\text { Прийоми оновлення змісту освіти, заснова- } \\
\text { ного на фрормуванні компетентностей, потріб- } \\
\text { них для успішної самореалізації в суспільстві }\end{array}$ & 0,411 & 0,85 & 1,1175 & 0,7065 \\
\hline ЗДОРОВ'ЯЦЕНТРОВАНА ОСВІТА & 2,4 & 3,6175 & 4,6175 & 2,2175 \\
\hline Практика збереження здоров'я & 0,85 & 1,5 & 1,5 & 0,65 \\
\hline Практика розвитку здоров'я & 0,85 & 1 & 2 & 1,15 \\
\hline Практика фрормування культури здоров'я & 0,7 & 1,1175 & 1,1175 & 0,4175 \\
\hline PA30M: & 10,6625 & 19,8905 & 24,3825 & 13,72 \\
\hline
\end{tabular}


виконували учасники за трьома номінаціями, були розроблені та пройшли апробацію на заняттях та уроках фрізичної культури (табл. 2).

Таким чином визначилися чемпіони та призери Ігор у кожній віковій категорії за кожною номінацією. Крім того, учасники суддівської бригади у процесі визначення результатів виконання завдань відмічали тих дітей та підлітків, які проявили свої унікальні здібності під час виступу (RESPECT від суддів).

Звісно, найпотужніший ефрект Ігор - спільна участь у важливій справі учасників, які різні не лише за віком і статтю, а також за соціальним статусом, рівнем здоров'я та обсягом власних можливостей. Успішний виступ залежав насамперед від того, як готувалися до виконання завдань учасники команди, як навчилися бачити, розуміти та підтримувати один одного.

Однак не менш важливим у межах підвищення кваліфікації педагогічних працівники освітній ефект їхньої участі у проєкті. Заради цього була розроблена схема, до змісту якої включені показники за п'ятьма розділами (табл. 3). За основу взяті результати емпіричного дослідження [2]. За кожним показником у схемі виставлялася самооцінка учасниками, які навчалися за програмою семінару та керівником семінару до початку навчання, по завершенні навчання та по завершенні проведення Ігор, після підведення підсумків. Шкала оцінювання: 0 - не володію; 1 - володію не в повній мірі; 2 - володію на достатньому рівні. Після цього підраховувався середній показник між самооцінкою та оцінкою керівника семінару; сумарний середній показник за кожним розділом схеми; загальний показник за всіма розділами схеми; динаміка показників.

Згідно 3 даними в табл. 3, за всіма показниками оцінки освітнього ефекту проєкту визначена позитивна динаміка $(+13,72)$. Найбільший приріст - за розділом «Персоналізована освіта» $(+3,415) ;$ найменший приріст - за розділом «Здоров'яцентрована освіта» (+2,2175). Припускаємо, що потужній приріст в оцінках за розділом «Персоналізована освіта» свідчить про низький рівень компетентності учасників семінару на початку проєкту, а також - вдало побудований процес навчання під час семінару за означеними в розділі складовими частинами.

Привернули увагу позитивні зрушення в оцінках по завершенні навчання на семінарі та після підведення підсумків Ігор $(+4,492)$. Фактична участь у реальних життєвих подіях, реолексивний аналіз власного внеску у спільний результат надали можливість педагогам підвищити самооцінку, зрозуміти цінність отриманих знань, умінь та відпрацьованих навичок під час участі в проєкті, збагатити власний педагогічний інструментарій. За такої умови найбільша кількість педагогів - учасників проєкту, акцентують, що саме діяльність стосовно визначення унікальних особливостей дітей і підлітків, а також дорослих - представників команд (RESPECT від суддів) зрушили їх погляд на інклюзію в позитивний бік.

Тому ті унікальні особливості учасників команд, які були виокремлені суддями, також варті уваги в контексті теми дослідження. Зокрема, RESPECT від суддів має такий вигляд: за підготовку чемпіонів; за завзятість; за чесне суддівство; за співпрацю; за партнерство; за обійми; за цілеспрямованість; за віру в себе; за прояв характеру; за наполегливість; за позитивність; за енергійність; за найбільшу популярність у мережі Інтернет; за рішучість; за продовження сімейних традицій у профресії. Поряд із зазначеним всі команди змагалися за номінаціями «Віртуоз», «Потужний дует», «Витривала команда». Ці відзнаки можна вважати додатковими балами освітнього ефректу навчально-методичного проєкту «Перші інклюзивні ігри», який вийшов за межі як спортивної зали, де відбувалися тренування учасників команд, так і за межі професійної компетентності педагогів - учасників семінару.

Висновки. Методика визначення освітнього есректу проєкту «Перші інклюзивні ігри» містить у собі п'ять розділів: компетентнісно орієнтована освіта; життєзначуща освіта; персоналізована освіта; кооперативна освіта; здоров'яцентрована освіта. До кожного із розділів включено по три показника. Змістове наповнення схеми, за якою визначався освітній еорект проєкту, віддзеркалює сучасний погляд на інклюзивну освіту загалом, а також - на місію педагогів у інклюзії. Проведене емпіричне дослідження дозволило встановити позитивну динаміку в самооцінках учасників семінару, в оцінках керівника семінару до початку навчання, по його завершенні, а також - після підведення підсумків Перших інклюзивних ігор «Ми разом». У перспективі - відпрацювання методики визначення освітнього ефекту інших фрорм підвищення кваліфрікації педагогічних працівників; корегування (модернізація) навчальних завдань для педагогів щодо складових частин схеми визначення освітнього ефекту.

\section{БІБЛІОГРАФІЧНИЙ СПИСОК:}

1. A educação física como método inclusivo para crianças com necessidades especiais / R.P. Diniz, Viana, F. Cury. Revista Científica Multidisciplinar Núcleo do Conhecimento. 2016. Ano 1. Vol. 9. Outubro / novembro. P. 235-253.

2. Методика визначення інклюзивного ефекту навчальних завдань педагогам на курсах підвищення кваліфікації (на прикладі дистанційної форми навчання) / О.П. Аксьонова, С.О. Авдєєва, І.В. Мінакова, Ю.В. Півненко. Modern education, training and 
upbringing : collective monograph. International Science Group. Boston : Primedia eLaunch, 2021. 594 p. URL: https://isg-konf.com (дата звернення: 25.08.2021).

3. Деделюк Н.А. Теорія і методика адаптивної фрізичної культури : навчально-методичний посібник для студентів. Луцьк : Вежа-Друк, 2014. 68 с.

4. Деякі питання підвищення кваліфрікації педагогічних і науково-педагогічних працівників : Постанова Кабінету Міністрів України від 21 серпня 2019 р. № 800 / Кабінет Міністрів України. URL: https://zakon.rada.gov.ua/laws/show/800-2019\%D0\%BF\#Text (дата звернення: 25.08.2021).

5. Національна стратегія розвитку освіти в Україні на період до 2021 р. : Указ Президента України від 25 червня 2013 р. № 344/2013 / Президент України. URL: https://zakon.rada.gov.ua/laws/ show/344/2013\#Text (дата звернення: 21.08.2021).

6. Про затвердження Концепції розвитку інклюзивного навчання : Наказ Міністерства освіти і науки
України від 01 жовтня 2010 р. № 912 / Міністерство освіти і науки України. URL: https://mon.gov.ua/ua/npa/ pro-zatverdzhennya-kontseptsii-rozvitku-inklyuzivnogonavchannya (дата звернення: 20.08.2021).

7. Трояновська М.М. Адаптивна фрізична культура : навчально-методичний посібник для студентів фракультетів фрізичного виховання / Національний університет «Чернігівський колегіум» імені Т.Г. Шевченка. Чернігів, 2018. 104 с. URL: http://erpub.chnpu.edu.ua:8080/jspui/bitstream/ 123456789/378/1/\%D0\%A2\%D1\%80\%D0\%BE\% D $1 \% 8$ F \% D 0 \% B D D 0 \% B E \% D \% B 2\% D $1 \%$ $81 \%$ D 1\% 8 C \% D 0\%B A \% D \% B 0_\% D 0\% 90\% D $0 \%$ B $4 \%$ D $0 \%$ B 0 \% D $0 \%$ B F \% D $1 \% 82 \%$ D $0 \%$ B 8\%D0\%B 2\%D0\%BD\%D0\%B 0\%20\%D1\%84\% D1\%96\%D0\%B 7\%D0\%B8\%D1\%87\%D0\%BD\% D0\%B0\%20\%D0\%BA\%D1\%83\%D0\%BB\%D1\% 8C\%D1\%82\%D1\%83\%D1\%80\%D0\%B0.pdf (дата звернення: 25.08.2021). 